\title{
Leadership and Statebuilding in Post-Colonial Africa: The Case of Cameroon
}

\author{
Leonide Awah*
}

\begin{abstract}
Changing perceptions of security threats post the 9/11 attacks in the United States of America saw the advancement of the idea that international security depended upon fixing fragile states. Based on this premise, statebuilding was constructed as a viable approach to building peace. The normative frameworks associated with peacebuilding have however, gradually given way to a narrow focus on institution building as statebuilding. In pursuing this approach, it is the case that the leadership of these processes is often underemphasised. This article interrogates the impact of this dominant narrative on states that are perceived to be peaceful. By bridging scholarship on the concepts of leadership and statebuilding generally, as well as scholarship on Cameroon's statebuilding process specifically, this article demonstrates that even for states that are not in conflict, periodic statebuilding is a useful requirement. This article departs from narrowly conceived ideas of leadership and statebuilding and brings into focus the role of leadership as a process in statebuilding practises in Africa. Based on the theoretical discussions and the empirical findings, this article demonstrates that leadership and statebuilding are mutually constitutive processes and leadership is the strongest single driver of an effective statebuilding process.
\end{abstract}

\section{Introduction}

The role of leadership in statebuilding remains highly problematic in most African states to date. ${ }^{1}$ At independence, African states were launched into international politics with statebuilding having been treated as an occurrence. It was assumed that states had been created with the granting of independence by colonial powers. This administrative approach to statebuilding often ignored the essential requirement of a relationship between state and society as an integral part of a statebuilding process. At the heart of some of Africa's most intractable conflicts are a range of issues regarding the nature of the state. The 1967 Biafra war in Nigeria, the civil war which occurred in Sudan and the secessionist war in Northern Mali are

\footnotetext{
${ }^{1}$ Mbembe, Achille (2001), On the post colony (Berkeley CA: University of California press)
} 
just some of the conflicts which call to question the nature of the statebuilding processes which took place in Africa.

Most states in Africa as they exist to date were a product of negotiations between the colonial administration and the African elite, with little influence from the societies that were meant to be led. ${ }^{2}$ As such, the challenge that faced leaders of newly independent African states was that of establishing a mutually beneficial social contract to regulate the relationship between state and society. By their very trajectory, most African states required a social contract to bridge the gap between what Peter Ekeh refers to as the 'Two Publics' that had emerged as a result of the colonial experience. ${ }^{3}$ In his time honoured theoretical statement about colonialism and the two publics in Africa, Ekeh attributes the state-society divide which exists in most African states to the existence of both the 'civic public', represented by formal inherited institutions, and the 'primordial public', built of ethnic norms and customs where the majority of society congregated. As a result of this divide, it was and still is essential for African statebuilding processes to bridge this gap through a robust state-society engagement. However, this requirement was in most cases overlooked and statehood assumed as a given. ${ }^{4}$ The lack of these processes in most African states has led to a variety of challenges including identity crises, coups and the persistence of 'weak states' unable to equitably deliver services to society. ${ }^{5}$

The Central African country Cameroon provides an excellent illustration of how the attempt to forge a state with little focus on societal cohesion produced a set of paradoxes. More than five decades after independence, attempts at statebuilding through institution building have not generated sufficient state legitimacy. To date, the Cameroonian state is characterised by the lack of consensus on the nature of the desired state, the inability of institutions to deliver services equitably and the presence of secessionist sentiments in the Anglophone regions of the country. ${ }^{6}$ However, dominant narratives that construct statebuilding as a post conflict endeavour have seen successive regimes reject attempts at statebuilding because they see this as an anomaly in peacetime.

\footnotetext{
2 Olonisakin, Funmi (2015), 'Re-conceptualising Leadership for effective peacemaking and human security in Africa', Strategic Review for Southern Africa, Vol: 37, Issue: 1

3 Ekeh, Peter (1975), 'Colonialism and the Two Publics in Africa: A Theoretical Statement', Journal of Comparative studies in society and History, Vol:17, Issue: 1, pp. 91-112

${ }^{4}$ Herbst, Jeffrey (2014), States and power in Africa: comparative lessons in authority and control (Princeton, NJ: Princeton University Press)

${ }^{5}$ Clapman, Christopher (2007), Africa and the International system: The politics of State survival (Cambridge: Cambridge University press)

${ }^{6}$ Kofele, Kale (1980), An African experiment in nation building: the bilingual Cameroon

Republic since reunification (Boulder: Westview press)
} 
Across Africa, countries that have engaged in deliberate statebuilding efforts are typically post conflict countries where international intervention has focused on statebuilding as a means of building peace. ${ }^{7}$ Underpinning this trend in statebuilding is the idea of 'liberal peace' which is built on notions of democracy and economic liberalisation..$^{8}$ Embedded in the idea of liberal peace is the assumption that democratic forms of governance are best suited to mitigating political conflict and ensuring peace. However, experiences across the continent have demonstrated that the absence of political conflict does not equate to the existence of functional relationships in society.

Building on Galtung's notion of 'positive peace' which he defines as the existence of social justice and the integration of society, this article posits that even in African states not in open conflict, it is essential to habitually re-engage in statebuilding conversations. ${ }^{9}$ To be certain, the essence of statebuilding is not only the creation of institutions, but the establishment of a state as an expression of social thought. However, dominant narratives of statebuilding as a post conflict endeavour have seen states like Cameroon which lack a functional state-society relationship reject impulses for statebuilding. This dominant perception poses a dilemma of how states perceived to be 'peaceful' engage in statebuilding conversations.

This article introduces an underemphasised element into this conversation: that of leadership. It is the case that the role of leadership is rarely interrogated in analysis of statebuilding processes in Africa. At first glance, the connection between leadership and statebuilding may not be apparent. However, leadership is best understood when viewed as a process of managing a complex situation in order to bring out a situation more desirable to both leader and followers. ${ }^{10}$ In situations of statebuilding, this involves meeting the common goals of both the leaders and the society in order to create a state that is desirable to both. Viewed as such, leadership and statebuilding become mutually constitutive processes and leadership emerges as the most compelling discursive framework for analysing statebuilding processes in Africa. This article thus provides a critical analysis of the role of leadership in the statebuilding process in Cameroon

\footnotetext{
${ }^{7}$ Olonisakin (2015), p. 9

${ }^{8}$ Richmond, Oliver and Jason Frank (2009), Liberal peace transitions: between statebuilding and peacebuilding (Edinburgh: Edinburgh University Press).

9 Galtung, Johan (1976), Three Approaches to Peace: Peacekeeping, Peacemaking and Peace-building. In Peace, War and Defence: Essays in Peace Research. Vol. 2, (Copenhagen: Christian Ejiers)

${ }^{10}$ Burns, James (2010), Leadership (New York: Harper Collins publishers). See also Bass, Bernard and Riggio, R. E. (2014), Transformational Leadership, (New York: Routledge)
} 
in order to demonstrate how leadership processes and decisions have shaped the outcome of states in Africa.

This article is divided in three parts, with the preceding being the introduction. Part one gives an overview of approaches to statebuilding in Africa before introducing the concept of leadership as process, highlighting its relevance for statebuilding in Africa. Part two focuses on Cameroon as a case study, analysing the statebuilding journey the country has gone through from independence till date. The role leadership played in this journey is analysed in this section. Part 3 analyses in further detail specific events in the statebuilding process, notably the 1991 sit down protest and the ongoing secessionist violence in the Anglophone regions. This detailed analysis of these specific occurrences establishes an enhanced conclusion on the nature of state-society relations in Cameroon.

\section{Approaches to statebuilding in Africa}

Statebuilding in Africa, mainly undertaken by international actors, has largely focused on the building of weak and fragile states. Changing Perceptions of security threats after the $9 / 11$ terrorist attacks contributed to shaping the dominant perception that international security depended on fixing weak and fragile states. ${ }^{11}$ As such, the normative frameworks often associated with peacebuilding such as democracy and human rights have progressively given way to a narrow approach of institution building as statebuilding.

The modern state is often defined as that institution which successfully claims monopoly over the means of force, is able to control its entire territory and can provide essential services to its population. With minimal alteration, this is the model of statehood on which contemporary states are based and the yardstick by which states are assessed. This model to a large extent underlies the practice of statebuilding by international actors. Most existing programs on statebuilding seek to establish a particular kind of state: a liberal state. This is one which upholds the rule of law, is democratic and market driven. ${ }^{12}$ This is evident in the nature of activities that comprise the statebuilding architecture traditionally offered by the international community.

\footnotetext{
${ }^{11}$ Rubin, Barnett (2008), The politics of security in post-conflict statebuilding, in Call, Charles T. and Wyeth, Vanessa (eds.), Building states to build peace (Boulder London: Lynne Rienner)

${ }^{12}$ Erikesn, Stein (2015), The Liberal Peace Is Neither: Peacebuilding, State Building, and the Reproduction of Conflict in the Democratic Republic of Congo in Young, Tom (ed.) Readings in the International Relations of Africa (Indiana: Indiana University Press)
} 
These normative frameworks that have come to characterise statebuilding in Africa often de-emphasise the relational nature of the state and the essential role of society as the basis for state legitimacy. This study thus takes a step back from this approach and adopts the legitimacy approach to statebuilding. The legitimacy approach, which is influenced by Durkheimian sociology, acknowledges the importance of creating institutions, but places more emphasis on the socio-political cohesion achieved in the process. ${ }^{13}$ Going by this approach, statebuilding becomes the establishment and reestablishment of public structure in a given territory such that they are capable of effectively delivering services to society. ${ }^{14}$ The re-establishment of public structure and the renegotiation of the social contract are essentially a leadership process.

\section{Introducing Leadership as process}

Leadership is one of the most sought after yet least understood phenomenon globally. It is a concept that means many things to different people. This is reflected in the study of leadership which spans various disciplines. Much of the study of leadership is, however, concentrated in organisational studies while the field of statebuilding, particularly in unstructured settings, is largely absent from leadership literature. To be certain, leadership is a multidimensional concept which eludes attempts at a precise definition. However, leadership scholar Keith Grint summarises the perceptions of leadership into four approaches, namely leadership as person, position, process and results. ${ }^{15}$

Leadership as person refers to the personal dispositions of the individual that make them a leader. Advocates for leadership as person base their analysis on the traits an individual possesses. The second approach which is leadership as position refers to the activity undertaken by an individual at the top of a vertical hierarchy in an organisation. Leadership as position looks at where leaders operate from in a social system. The third leadership approach which is leadership as results refers to the outcome of leadership endeavours. This is understandable because results are the basis on which leadership effectiveness is measured. However, in statebuilding conversations focusing on results only could be counterproductive, as the process through which results are achieved is as important as the results.

\footnotetext{
${ }^{13}$ Durkheim, Emile (1957), Professional Ethics and Civic Morals. Translated by Cornelia Brookfield. (London: Routledge and Kegan Paul)

${ }^{14}$ Bogdandy, Armin and Rüdiger. Wolfrum (2005) eds, State-Building, Nation-Building, and Constitutional Politics in Post-Conflict Situations: Conceptual Clarifications and an Appraisal of Different Approaches (Koninklijke Brill NV: Leiden)

15 Grint, Keith (2010), Leadership: A Very Short Introduction (Oxford: University Press)
} 
Perspectives of leadership as person, position and result which are predominant in developing societies tend to ignore the relational nature of leadership in which leaders and followers are bound by mutual goals. In statebuilding, effective leadership comes into being when leaders mobilise institutional and political resources to achieve the common goals of the society they lead. It is through this relationship built in the pursuit of common goals that the legitimacy of state authority is obtained. ${ }^{16}$ As such the fourth leadership approach - leadership as process - which Peter Northhouse defines as the process by which an individual influences a group of people towards the achievement of a common goal, stands a better chance of bridging the predominant disconnect between the state and society in much of Africa. ${ }^{17}$

Leadership is best understood when viewed as a process of managing a complex situation in order to bring about a more desirable situation. In situations of statebuilding, this involves meeting the aspirations of both the leaders and the society in order to create a state that is desirable to both. Viewed as such, leadership and statebuilding become mutually constitutive processes and leadership emerges as the most compelling discursive framework for analysing statebuilding processes in Africa.

\section{A focus on Cameroon: Historical background of the state}

Cameroon's statebuilding experience has seldom made headlines. This can be attributed to the fact that up until 2012 when the Boko Haram menace extended into the country's far North region, the country had not been involved in any major conflict. However, beneath the apparent stability lay a range of challenges that threatened state survival. While statebuilding favoured the penetration of the Weberian state into society, gaping holes in the practice of leadership failed to generate state legitimacy. As such, the statebuilding process has been far from linear, with challenges that continue to have an impact on extant performances of statehood. While the focus of this article is not on the historical evolution of the state, knowledge of the historical background of the state is essential. The dual colonial heritage has proven a major challenge for statebuilding especially given the fact that the country has a history of major challenges in the practice of leadership.

\footnotetext{
16 Lemay, Hébert (2014), Semantics of State building and Nation Building: Looking beyond Weberian approaches in Lemay, Hébert (ed.) Semantics of Statebuilding: language, meanings and sovereignty, (London: Routledge)

17 Northhouse, Peter (2016), Leadership: theory and practice (Los Angeles: SAGE Publications)
} 
The state of Cameroon came into being after the ethno-political entities that inhabited that geographical area were colonised by the Germans, who after defeat in World War I handed the territory to the French and British. For over four decades, French and British Cameroon's were administered as separate entities, engineering a linguistic, administrative and socio-political divide which would later pose a major challenge for statebuilding efforts post-independence. ${ }^{18}$

Historians argue, perhaps rightly so, that the French system of assimilation had left the elite in French Cameroon (at that time referred to as East Cameroun) unable to harbour an independent political ideology outside of the French Union (Union Française). ${ }^{19}$ Thus, the attainment of political independence by French Cameroun in 1960 was described by analysts as a facade. ${ }^{20}$ To a large extent, Cameroon remains a neo-colonial entity under the domination of France with little benefits of its independence accruing to the majority of Cameroonians. ${ }^{21}$ The attainment of independence, the occurrence of which officially kicked off Cameroon's statebuilding process, was fraught with conditionalities and institutional arrangements which dictated limited possibilities of what the new state could become. ${ }^{22}$ When in 1961 British West Cameroon voted to attain independence by joining the Republic of Cameroun, this decision entailed an adherence to already established institutions and bureaucracies, with limited political will for reform. ${ }^{23}$

\section{Leadership in Cameroon's Statebuilding Process}

What can be considered Cameroon's statebuilding process began with the attainment of independence by French Cameroun in 1960, and the

\footnotetext{
18 Ashew, Andrew (2016), Political philosophies and Nation Building in Cameroon: Grounds for remaking the Post Colony (Bamenda: Unique Printers)

19 The Union Française was created with the enactment of a new French Constitution in 1946. Known as the constitution of the fourth Republic, it sought to transform French colonies into overseas territories.

${ }^{20}$ Ngayap, Pierre (1983), Cameroun, qui gouverne? De Ahidjo a Biya, l'héritage et l'enjeux, (Paris: L'Harmattan), see also Atangana, Matin (2010), The end of French rule in Cameroon. (Lanham:University Press of America)

21 Van de Wall, Nicholas (1993), The politics of Nonreform in Cameroon in Callaghy, Thomas and Hemmed, John (1993), Hemmed In responses to Africa's economic decline (New York: Columbia University press)

22 Terretta, Meredith (2014), Nation of outlaws, State of Violence: Nationalism, Grassfields tradition, and State Building in Cameroon (Athens, OH: Ohio University Press)

23 Bayart, Jean Francoise (1973), "One-Party Government and Political Development in Cameroun," Journal of African Affairs, Vol: 72, Issue: 287, pp. 125-144; Van de Wall (1993), p. 389
} 
unification of the two territories in $1961 .{ }^{24}$ The journey towards unification was however fraught with complex, sometimes contradictory processes. Before the attainment of independence by French East Cameroun in 1960, the idea of reunification with British West Cameroon had been a subject of political mobilisation, albeit led by different actors. Prior to independence, a nationalist movement known as the Union des Populations Camerounaise (UPC) had actively led the campaign for unification as a pre-condition for independence. ${ }^{25}$

Many accounts of Cameroon's statebuilding trajectory do not fully appreciate how crucial the nationalist objective of re-unification before independence was. It was the objective of the nationalists to cement a United State of Cameroon that would prevent the incorporation of any part of the combined territory into a post-colonial union with the colonialists. ${ }^{26}$ The nationalist's opposition to the idea of a single union under French tutelage and their radical demands for independence was a source of discomfort for the administration who had a crucial policy aim of maintaining influence in the country. ${ }^{27}$ As such, following a series of strikes in May 1955, the UPC was outlawed and thus unable to participate in independence and unification negotiations.

What is most telling is the fact that by 1955 when the UPC was outlawed, French influence in the country had moved beyond the socio-political to include other economic and strategic interests. ${ }^{28}$ Cameroon had openly become a French strategic territory. In order to maintain French influence in the country, it was inherent that the Cameroonian political elite who were to take over leadership of the country be largely products of French assimilation. Thusrather than engage leadership as process in order to identify individuals who shared a mutual interest with the society to lead the country to independence, the colonial administrators sought to install individuals who shared a mutual interest with them. As such, Amadou Ahidjo, a little known political figure who began his political journey in a French sponsored party known as Bloc de Democratie Camerounaise

\footnotetext{
24 Under colonial administration the Eastern part of Cameroon which was administered by the French was known as French Cameroon or East Cameroon, and the part administered by the British was known as British Southern Cameroons 25 Joseph, Richard (1977), Radical Nationalism in Cameroun: Social Origins of the UPC Rebellion (Oxford: University Press); Terretta (2014), pp. 19-26

26 Willard, Johnson (1970), The Cameroon Federation: Political Integration in a

Fragmentary Society (Princeton: Princeton University press)

27 Deltombe, Thomas, Domergue, Manuel and Tatsitsa, Joseph (2011), Kamerun!: une guerre cachée aux origines de la Françafrique (1948-1971) (Paris: La Découverte)

${ }_{28}$ Ngayap (1983), pp.11-16; Joseph (1977), pp. 20-32
} 
(BDC), was appointed Prime Minister from where he rose to become the first post-independence President. ${ }^{29}$

Unlike Um Nyobe, the leader of the UPC who had a vision for a unified state which he articulated publicly, there exists no historical account of any public utterance by Ahidjo that spoke of a nationalist agenda, much less an agenda for unification. ${ }^{30}$ Also, unlike other post-independent leaders such as Juluis Nyere of Tanzania and Nkwame Nkrumah of Ghana who had led independence movements and promoted Pan African ideals, there is little or no record of Ahidjo partaking in Cameroon's nationalist struggle. The independence and nationalist agenda in Cameroon was animated solely by the UPC, which was barred from taking part in the elections by the French colonial government. This was to have an enormous impact on Cameroon's statebuilding trajectory. The handing over of the task of building a state facing a historical challenge to a ruler, who had not come to terms with the complexity of this challenge, played a key role in the story of Cameroons failure to become a legitimate unitary state.

\section{The war against the Nationalist movement and its impact on Statebuilding}

The primary focus of the post-independence government was to suppress the nationalist movement, namely the UPC. The UPC movement which had led more than a decade long struggle against colonial rule continued its activities post-independence, defying the authority of the handpicked government. The persistence of the nationalist movement in postindependent Cameroon raises important questions as to the rationale for considering political independence as the watershed event in Africa's decolonial process. Choosing political independence as the end of the decolonial process often limits analysis of the impact of pre-independence events on post-independence statebuilding. Yet the aftermaths of these events are crucial to the understanding of what kind of states post-colonial territories became.

Such is the case with the UPC whose pre-independence ban had an enormous effect on statebuilding. With the assassination of $\mathrm{n}$ ationalist leaders and political exclusions caused by the ban on certain parties, the

\footnotetext{
${ }^{29}$ From 1958 the French colonial government granted internal autonomy to French Cameroon in preparation for independence. A government was setup with handpicked representatives. Ahidjo was appointed Prime minister in the pre-independence government in 1958 from where he ran for the position of president ahead of the attainment of independence in 1960. For a discussion on pre-independence politics see Joseph (1977), pp. 430-438

${ }^{30}$ Aseh (2016), p. 13
} 
independent state was modelled on the Françafrique ideal which the UPC had fought against. The UPC struggle for independence from French rule in Cameroon amounted to a struggle to define on their terms what constituted legitimate statehood and political practice in Cameroon. Thus, the handover of the country to appointed leaders who let French advisers continue to run the country was seen by the UPC as an illusory independence. The UPC therefore vowed to continue with the internal insurgency in order to obtain 'complete' independence from what they considered to be a neo-colonial regime led by Ahmadou Ahidjo. ${ }^{31}$

President Ahidjo, cognisant of the fact that the UPC enjoyed popular legitimacy during the transition, made it his primary task to eliminate the UPC rebellion. He was assisted in this regard by the just exited French authorities whose interests he effectively represented. With the threat from the UPC finally contained through an unreported war, Ahidjo proceeded to actualise his ultimate goal: the creation of a centralised unitary state. This he did, in contravention of Article 47 of the constitution of 1961 which stipulated that any revisions to the federal structures established at unification were to be inadmissible. ${ }^{32}$ This outright violation of constitutional provisions, the limited mutual relationship between the postindependent elites and society, and the use of coercion in the statebuilding process shaped the Cameroonian state into the hollow political structure it became and remains till date.

\section{Leadership and the move from a Federal to Unitary State}

While a vast majority of Cameroonians were still trying to figure out the implications of unification under the federal system of government, the federal structures were dismantled in favour of a highly centralised unitary state. It is generally agreed that federalism, as it has been practised over the years, is often shaped and refined by local exigencies. In Cameroon, the federal bargain was an attempt to create a form of government whereby both territories would be substantially independent to the extent required for integration.

This was the more practical form of government at this time especially for the former British Southern Cameroon. However, given that federalism was incompatible with the totalitarian rule sought by Ahidjo, he began to

\footnotetext{
${ }^{31}$ Aseh (2016), p. 33, Terretta (2014), pp. 9-17

32 The 1961 Constitution of the Federal Republic of Cameroon is reproduced on pages 253-266 in Enonchong, Henry (1967), Cameroon constitutional law: federalism in a mixed common-law and civil-law system (Yaoundé: Centre d'edition et de production de manuels et d'auxiliaires de l'enseignement)
} 
intentionally undermine the federal structures. From an outright rejection of proposals to the federal constitution, to the centralisation of the resources of the federated state, Ahidjo ensured the redundancy of the federal governments. Having succeeded in imposing a highly centralised form of federalism, Ahidjo gradually undertook to realise his ultimate goal of establishing a unitary state.

On May $6^{\text {th }} 1972$, Ahidjo proceeded to announce in the national assembly that he intended to transform the federal republic into a unitary state should the electorate support the idea in an upcoming referendum. ${ }^{33}$ However, the decision to have a referendum and the proposed date were all decisions made by the executive and communicated to the electorate, rather than it being the decision of the electorate. Ahidjo ignored the need to engage with the Cameroonian society to be able to ascertain societal aspirations for statehood and instead employed tactics such as patronage, sabotage and coercion to ensure that federal structures were dismantled in favour of a unitary state.

When Ahidjo suddenly resigned from power in 1982, his successor Paul Biya inherited a highly centralised state which he proceeded to perfect by putting in place measures to ensure that all power was vested in the office of the President. He ensured that as the Head of State and of government, he was completely in control of the other two arms of government- the legislature and the judiciary. As President, he had the power to appoint all ministers, heads of parastatals, governors and even Supreme Court judges. As such most of his appointees were more loyal to the Head of State than to the population they were meant to be serving. Biya's ascension to power was the start of a process of sophisticated power management that oppressed groups and alienated large swathes of society in Cameroon. ${ }^{34}$

This sophisticated power management anchored on systems of domination, divide and rule, unofficial political machinery and unpredictability led to what Achille Mbembe describes as the impotency of the state and citizens. ${ }^{35}$ With the resignation of Ahidjo and the ascension of Paul Biya to power, the majority of Cameroonians had hoped for a transformation of state-society relations under the new dispensation. Disappointment with the outcome of the transition and exasperation with the cycle of power manipulation saw

\footnotetext{
33 Cited in Konings (1999), p. 303

34 Bachmann, Olaf (2013), Quasi Armies: Obstacles to, or Vehicle for State-Building in Central Africa (PHD Thesis: Kings College London) Retrieved at https://kclpure.kcl.ac.uk/portal/files/12625097/StudentthesisOlaf Bachmann_2013.pdf 35 Mbembe (2001), pp. 21-25
} 
Cameroonians lose faith in the system and retreat from political participation.

Biya, who up until his appointment was a career bureaucrat, thus consolidated his presidency and established himself as supreme ruler. The effect of this was the ineffective management of institutions, economic decline and the outright neglect of societal aspirations, as all political compasses focused on the consolidation of power. An attempted coup in 1984, which by some accounts was staged by President Biya himself, provided an additional opportunity for regime consolidation. ${ }^{36}$ In an attempt to consolidate power, Cameroon's post-colonial leaders enacted and maintained policies that weakened the state.

The distribution of resources based on systems of patronage rather than equitable distribution saw patronage emerge as the new social contract. The absence of a viable social contract between state and society saw the decline of civic trust and the erosion of state legitimacy. Leadership in Cameroon's statebuilding process departed from leadership as a process of influence to leadership as a person, with coercive power as the basis of influence. The effect of this is self-evident in Cameroon's statebuilding outcome, which is a state that has consistently been unable to meet the needs of society, to the extent that the legitimacy of the state is being challenged. Despite several episodes of challenges to state legitimacy, with the most recent coming from the anglophone regions of the country, the regime persists in its rejection of any dialogue that touches on the nature of the state.

In order to analyse the relationship between leadership and statebuilding, the next section will focus on leadership responses to longstanding grievances of the anglophone population including the most recent episode of calls for secession. It further identifies the leadership responses to the 1991 and 2016/2017 'ghost town' actions as the main discursive events. It seeks to identify specific discourses that were employed and actions that were taken in response to the crises and whose interests they were meant to serve. A couple of factors inform the choice of these particular events as the main discursive events. First, the Cameroonian state as it currently exists depends on a patchwork of national unity between former East and Southern Cameroon. As such, protests from the Anglophone quarters in former Southern Cameroon pose a risk for the statebuilding efforts. In addition, the 'ghost town' actions are underpinned by issues of governance

\footnotetext{
${ }^{36}$ Interview with General Semengue quoted in Bachmann, Olaf (2012), p.193 see also Fenkam, Federick (2003), Les révélations de Jean Fochivé, Chef de la police politique des présidents Ahidjo et Biya (Paris: Tameris)
} 
and identity which are all important considerations in leadership and statebuilding processes.

\section{Leadership responses to Anglophone Particularist Sentiments}

When on the $4^{\text {th }}$ of February 1984 President Biya, without consultation, unilaterally changed the official name of the country from 'United Republic of Cameroon' to 'Republic of Cameroon', the most vocal protests came from the Anglophone minority. ${ }^{37}$ Anglophone Cameroonians saw the return to that name as evidence that Biya was trying to assimilate former British Southern Cameroon into becoming an indistinguishable part of the Republic of Cameroun. This event thus became the official representation of a series of struggles that had come to be known as the 'Anglophone problem' in Cameroon.

In the Cameroonian context, an Anglophone is anyone who hails from the North West and South West regions of the country and whose first language is English. ${ }^{38}$ However, for a more nuanced analysis, this study focuses less on the language element and uses the term Anglophone to refer to citizens who hail from what was formerly known as British Cameroon. This is made necessary by the fact that in the current political climate, the veracity of language as a marker of regional identity has been diminished. The study therefore uses the term Anglophone and Francophone in their historical context.

At independence, the Cameroonian state faced the daunting task of managing this dual colonial legacy. The more than four decades of separate colonial experiences had left a legacy beyond linguistic differences. There existed cultural and socio-political differences which required harmonisation. The task of ensuring successful harmonisation of these different identities lay with the first post-independence President, Ahmadou Ahidjo. However, largely considered as a puppet of the French, Ahidjo enjoyed very limited support within the larger society in Cameroon. He thus relied on repression, centralisation of power and coalition building to consolidate his power. ${ }^{39}$

\footnotetext{
37 Konings Piet and Nyamnjoh Francis (1997), "The Anglophone Problem in Cameroon," The Journal of Modern African Studies. Issue: 35, Vol: 2, pp. 207-229

38 These two regions previously constituted what was known as British Southern Cameroon. At the time of writing they are the majority Anglophone regions, and play host to the leading opposition parties

39 Bayart (1985), pp. 39-42. See also Richard Joseph (2002), Gaullist Africa: Cameroon under Ahmadu Ahidjo (Enugu: Forth Dimension Publishing Co)
} 
The result of this was a constitution that favoured a highly centralised form of federation where former West Cameroon lost all autonomy. The final version of the constitution of the federal republic which was never presented to the Anglophone delegates granted the President sweeping powers. ${ }^{40}$ With the introduction of a centralised form of federation, Ahidjo ensured that the federal state governments became ceremonial bodies with very little power. In 1962, Ahidjo replaced the West Cameroon pound sterling with the CFA, and in so doing assimilated Southern Cameroon into the French Economic Union. Exports from the two Southern Cameroonian ports of Tiko and Limbe were diverted to the Port of Douala, located in East Cameroon. This led to a loss of jobs, and the abandonment of development projects in Southern Cameroon. ${ }^{41}$

All these led to economic hardships and dissatisfaction amongst the people of Southern Cameroon. Dissenting opinions were ignored by Ahidjo as he carried out state reforms in an autocratic manner. Citizens who criticised the system of governance were arbitrarily arrested, tortured and some forced into exile. Wanton arrests, forced disappearances and public executions were some of the techniques used to ensure the fear of the state and its agents. The militarisation of the state and the atmosphere of terror saw Cameroonians retreat from active participation in governance processes, and what was once a dynamic population who had put up an active resistance to colonial rule became a passive population unable to hold government to account.

The larger society in Cameroon withdrew from political engagement, with elites choosing to ignore the authoritarian practices of the regime in exchange for a share of the benefits of patronage. The dominance of patronage and clientelist networks led to the transformation of sites of authority. Access to key positions in the public service, the military and even access to finance depended on one's networks. ${ }^{42}$ The alienation of much of society from the centre of state power and the personalised nature of politics based on networks left the Anglophones feeling that the unification had done nothing but impede former Southern Cameroon's economic and socio-political development. 43

\footnotetext{
${ }^{40}$ Konings (1999), pp. 52-60

${ }^{41}$ Konings and Nyamnjoh (1997), pp. 220-224

${ }^{42}$ Arriola, Leonardo (2013), Multi-ethnic coalitions in Africa: business financing of opposition election campaigns (New York: Cambridge University Press)

${ }^{43}$ ICG interview with Anglophone academics in Cameroon cited in International Crises Group Report (2017), Cameroon's Anglophone Crisis at the Crossroads, Africa Report No:250, Available online at https://www.crisisgroup.org/africa/centralafrica/cameroon/250-cameroons-anglophone-crisis-crossroads (Accessed 19 May 2019)
} 
The frustrations only worsened with the discovery of oil in former British Southern Cameroon. All revenue from the exploitation of oil was firmly controlled by the executive and his inner circle. This revenue was kept out of the national budget in an offshore account, supposedly meant to be used for development projects. ${ }^{44}$ One issue that has continued to reverberate in the minds of the Anglophones from the Ahidjo through the Biya era is the secondary role Anglophone's exercise in matters of public affairs and therefore in the building of the Cameroonian state. As such, with the gradual opening up of democratic space in the early 1990's, the Anglophones took advantage of the opportunity to make known their grievances.

\section{Leadership responses to the 1991 'Ghost Town' Actions}

For over twenty-five years, Cameroonians lived under a one-party system where leadership was conceived and practiced as a mystical phenomenon. Despite declarations to the contrary, there was little room for political or leadership development. The technique of silencing critics and the repression that had characterised all of Cameroon's post-colonial life had led to the development of a culture of silence and abdication of the responsibility to hold government to account. As such, it was easy for the regime to perpetuate a narrative of stability and effective statebuilding.

However, Cameroon's statebuilding process was to be put to the test in 1991 when, exasperated with the political and economic crises, opposition leaders proposed a national conference to discuss political reforms. This was indeed, an impulse for statebuilding and a demonstration of the fact that leadership was occurring across different levels of society. However, the dominant perception of leadership as a top-down phenomenon resulted in the rejection of this attempt. All initiatives by the opposition were promptly repressed by the government. The opposition thus decided to call for 'Ghost town actions', to force the government to the dialogue table. 45 Between April 1991 and January 1992, the opposition issued calls for the society to immobilise economic activity by staying indoors, shutting down businesses and refusing to pay taxes or bills. ${ }^{46}$

The most telling incident in the crises which demonstrated the absence of mutuality in Cameroon's leadership process occurred in June 1991 when, in disregard of the fundamental grievances underpinning the crises, President Biya declared that a national conference was a pointless exercise. He

\footnotetext{
${ }^{44}$ Van de Wall (1993), p. 85. See also Arriola (2013), p. 117

45 Nyamnjoh, Francis (2011), Mass media and democratisation in Cameroon in the early 1990's (Mankon: Langaa Press)

46 Nyamnjoh (2011), p. 13
} 
insisted that law and order will be enforced no matter what it took. 47 Despite the obvious hardship that the ghost town actions posed for the entire society, the political leaders demonstrated a sound ability to dissociate from issues of common interest. During the ghost town actions, while $70 \%$ of the country had been crippled by protest action, the central government sitting in the capital, Yaoundé, continued its daily bureaucratic functions in complete disregard of the crises going on. Also, given that the media houses were state owned, there was little media coverage of the street protests. ${ }^{48}$

The fact that the central administration continued its normal operations unperturbed while half of the country was on lock down demonstrated a complete lack of mutuality between the leaders and society. This lack of mutuality was further demonstrated by President Biya's absence from the negotiations with the opposition. ${ }^{49}$ Instead of engaging in genuine dialogue with the opposition in order to find a solution that met the aspirations of state and society, President Biya kept away from the negotiations. He relayed information through appointed representatives. It thus became a situation of crises management, as opposed to a statebuilding conversation anchored on mutual goals of the state and the larger society.

By October 1991, the strain of the strike had begun to weigh heavily on society. Those particularly hit were women and young people, who are systematically locked out of formal political processes and from the formal economy despite constituting a majority of the population. A majority of women, particularly in the rural areas who earn their living from petty trade, were the hardest hit by the crises. Economic hardship, lack of access to goods and services and dissatisfaction with the means employed by the opposition forces caused the resistance to dwindle. Also, the fact that the government was able to function uninterrupted led to loss of hope in getting the government to dialogue on mutually beneficial terms. The eventual negotiations were done strictly on Biya's terms: he decided what was essential for negotiation and in the process left out key requests such as proposals for decentralisation of power.

Today, Cameroon is a multi-party state but the authoritarian one-party logic still stands. Those who do not share the same political platform or ideology as the ruling party are frustrated out of economic opportunities even in the

\footnotetext{
${ }^{47}$ Speech by president Biya delivered on the $21^{\text {st }}$ of June 1991, cited in Nyamnjoh (2011), p. 13

${ }^{48}$ Nyamnjoh (2011), p. 18

${ }^{49}$ Nyamnjoh (2011), pp. 20-23
} 
private sector which has been totally infiltrated by the state..$^{50} \mathrm{As} \mathrm{such}$, most political parties still abide by the logic of the ruling party. The response to the ghost town actions illustrate the crucial leadership challenge in Cameroon in which the state is removed from the very needs and aspirations of the larger society.

The gaping holes in the leadership process were however, not limited to the government quarters. The main opposition party also demonstrated an inability to see leadership as a process anchored on the needs of society. The intolerance towards those opposed to the opposition's strategies led to a decrease in the larger society's confidence in the opposition. A section of the opposition movement resorted to violence, arson and intimidation as a means of ensuring compliance with the ghost town actions. The opposition employed the same coercive tactics that the government was being criticised for. Though the opposition leaders tried to distance themselves from the perpetrators of these acts, these events nonetheless cast a shadow on the ability of the opposition leaders to secure direction for the society. This same scenario was to repeat itself in the more intense Anglophone protest which took place years later.

The ghost town action ended with a couple of piecemeal reforms, but very little systemic change. The state-society relationship thus remained dysfunctional. This dysfunctional situation persisted for another two decades alongside governance deficiencies, economic crises and exclusion. What exists in the country is negative peace beneath which lie tensions and unresolved grievances. ${ }^{51}$ However, due to the dominant perception of statebuilding as a post conflict endeavour, attempts to initiate statebuilding conversations continue to be ignored even in the face of a three-year long protest by Anglophones which began in 2016 .

\section{Leadership responses to the 2016 protest action and its impact on statebuilding}

More than two decades after the struggle for political reform, the state apparatus remains dominated by sustained governance failures, constitutional manipulation and a massive state-society disconnect. ${ }^{52}$ The fragility of Cameroon's statebuilding process was once again demonstrated in October 2016, when a series of sectorial grievances morphed into strikes

\footnotetext{
50 Leonardo (2013), pp. 47-50

51 International Crises Group (2014), “Cameroon: Prevention Is Better than Cure”, Africa

Briefing $N^{\circ} 101$, Available at https://www.crisisgroup.org/africa/central-

africa/cameroon/cameroon-prevention-better-cure (Accessed 18 August 2019)

52 Mbaku and Takougang (2004), pp. 90-93
} 
and a demand for the re-arrangement of state structures by the Anglophone population. ${ }^{53}$ Far from being an isolated incidence, grievances over state performance have seen frequent outburst across the country. In 2007, protests over the rise of fuel prices quickly became an anti-political leadership campaign. Youths across the country took advantage of the momentum to protest against massive unemployment, poor infrastructure and the leadership inertia that characterised much of public life in the country. The response from the government was repression and refusal to acknowledge the protests as a statebuilding conversation due to the inefficacy of formal channels of engagement.

The inefficacy of formal channels of engagement saw lawyers in Bamenda, the largest city in the North West region take to the streets in protest. On October $16^{\text {th }}$ 2016, after several petitions to the government went unanswered, lawyers from the Northwest and the Southwest (both Anglophone provinces) went on strike. The lawyers demanded the translation of all legal texts to English as stipulated by the constitution and the withdrawal of French speaking Judges from Common Law courts. ${ }^{54}$ The lawyers were soon joined by motor-bike riders and other disenfranchised youth who were exasperated with the system of governance. The security forces promptly stepped in and violently dispersed the crowd, brutalised some lawyers and arrested several motorbike drivers. In response, some youth set up roadblocks and engaged security officials in running battles, which left scores dead and several others wounded. 55

Faced with the crisis, the government began talks with the striking unions. The talks were, however, led by the Prime Minister, an individual largely considered as a figure head with no real powers in the bureaucracy. Ignoring the need for genuine dialogue and with no formal address to the nation, President Biya set up a committee to manage the crisis. The agenda of the committee, its presiding officers and its plan of action were all unilaterally decided by the Head of State with little input from the society the committee was meant to serve.

In December 2016, the government announced the recruitment of more bilingual teachers, a two billion FCFA grant to private schools and the redeployment of Francophone teachers. ${ }^{56}$ However, these measures came

\footnotetext{
${ }^{53}$ ICG (2017), p. 9

${ }^{54}$ Author accessed copy of statement of demand from lawyers from the secretariat of the Cameroonian Bar Association.

${ }^{55}$ Report submitted by the (Commission nationale des droits de l'Homme et des libertés, CNDHL)

56 See Cameroon Tribune No: 8080, 13 March 2017
} 
too late, as the sectorial demands by the lawyers and teachers had already morphed into political demands that included long standing questions about the nature of the state. There were demands for the return to the federal state with some radical groups advocating for complete secession of former British Southern Cameroon. ${ }^{57}$

Unwilling to entertain any genuine dialogue that touched on statebuilding, the government arrested Anglophone leaders and charged them with terrorism and plotting to destabilise the state: allegations the prosecution was largely unable to prove. Following the arrests and continuous police brutality, what was left of the negotiations between the crisis committee and the teachers union collapsed. Subsequently, pockets of Anglophone leaders and a couple of diaspora-based activists initiated 'ghost town actions' and called for students to boycott schools. In response, the government reinforced its military presence and disconnected access to internet services for 92 days in a move the government argued was aimed at curbing online propaganda and 're-establishing state authority'.58

The months that followed saw school boycotts continue, sit-down protests intensify and everyday life disrupted in the two Anglophone regions. However, in similar fashion to the 1991 protest, the central government continued its bureaucratic functions in complete disregard of the chaos in the two Anglophone regions of the country. While everyday life continued as usual in the other eight regions of the country, students in the Anglophone region who had been forced to stay home for fear of reappraisals wondered when the crises would be resolved so they could resume normal life like their peers. The deadlock continued for several months causing students to lose an entire academic year while it was business as usual in the Francophone parts of the country. The perceived lack of empathy from the French speaking population raised questions in the Anglophone quarters as to the level of cohesion in the country. ${ }^{59}$

As such on the $1^{\text {st }}$ of October 2017, the anniversary of reunification between the two states, Anglophone separatists, following months of online mobilisation, decided to declare a symbolic independence of what they termed 'Ambazonia' by hoisting flags and renaming streets. The activities attracted a violent response from security forces and in the confrontation

\footnotetext{
57 Vaudran, Liesl (2017), "There's more to Cameroon's protest than meets the eye" Institute for Security Studies: South Africa. Available at https://issafrica.org/amp/isstoday/theres-more-to-cameroons-protest-than-meets-the-eye (Accessed 17 August 2019)

${ }^{58}$ ICG (2017), p. 11

${ }^{59}$ ICG (2017), p. 26
} 
that ensued more than 17 civilians were killed by security forces. ${ }^{60}$ This reappraisal radicalised the separatists who began carrying out armed attacks against security forces. In December 2017, following the explosion of improvised devices in Bamenda, President Biya, who had not publicly commented on the crises almost 18 months since its inception, declared war on the Anglophone separatists. ${ }^{61}$ This was followed by brutal killings by security forces and burning of entire villages suspected to be hosting separatist elements. This only emboldened a faceless group known as 'The Ambazonian Army' which had emerged from the crises. Alongside the attack on security forces, this group began kidnapping government officials and intimidating the Anglophones who had contrary opinions about their methods.

The violence between the two groups has seen hundreds killed, thousands displaced and caused a massive divide along linguistic lines on a scale not witnessed since unification. This widening rift in society was made worse by the lack of political will to address the underlying grievances and the lack of coordination amongst the Anglophone groups makes possible solutions even fewer. Three years since the onset of the conflict, the insecurity in the Anglophone regions has spiralled out of control. Secessionist groups have grown in ranks and the two Anglophone regions have effectively become war zones with daily reports of killings, maiming and kidnappings by both the security forces and the secessionist fighters. Tens of thousands of people have fled to Nigeria or become internally displaced people as a result of the violence.62 However, the government in its official statements continues to downplay and even out rightly deny the gravity of the current crises.

Reframing narratives of statebuilding away from statebuilding as a strictly post conflict endeavour to statebuilding as a process of enhancing statesociety relationships will provide an opportunity for the Cameroonian state to reconcile the Anglophone community and set them back on the course of statebuilding. The response to the $2016 / 17$ protest which is still on-going at the time of writing which range from denial to brutal repression speak to the massive disconnect between the state and society. The situation calls for

\footnotetext{
${ }^{60}$ Quartz Africa (2017), 'Cameroon's “Anglophone” crisis has reached a boiling point as security forces kill 17 protesters', Available at https://qz.com/africa/1092006/cameroonanglophone-crisis-police-kill-15-southern-cameroons-independence-protestors/ (Accessed 17 August 2019)

61 Televised Speech delivered by the president of the Republic on the $17^{\text {th }}$ of October 2017

62 UNHCR 2018 Report 'Fleeing violence, Cameroonian refugee arrivals in Nigeria pass $30,000^{\prime}$, Available at https://www.unhcr.org/news/briefing/2018/11/5be551224/fleeing-violencecameroonian-refugee-arrivals-nigeria-pass-30000.html (Accessed 17 May 2019)
} 
a deliberate process of statebuilding that is anchored on the mutual needs of the elites and the larger society.

\section{Conclusion}

Despite the robust engagement with the issue of statebuilding, it is the case that the role of leadership in statebuilding processes is often underemphasised. This article has analysed the role of leadership in statebuilding processes in Africa, with the intention of demonstrating two key points. First, that due to the massive state-society divide in most states, statebuilding should serve to enhance the relationship between state and society, based on mutually shared goals. As such leadership and statebuilding are mutually constitutive processes.

Secondly, it demonstrated that if statebuilding is viewed as the process of enhancing state-society relationships, then statebuilding is an appropriate exercise even for states perceived to be peaceful. The relevance of this assertion has been demonstrated using Cameroon's statebuilding trajectory. Evidence from two discursive events, the 1991 ghost town actions and the on going secessionist violence, reveal a massive disconnect between state and society in Cameroon. These events demonstrate that there exists a dire need for a statebuilding conversation. The responses to these particular events also demonstrate that leadership positions are occupied by individuals who are not exercising leadership.

The superficial engagement with the grievances underpinning the crises demonstrates a lack of mutuality between the state and much of society. This absence of mutuality has seen the enactment of policies that serve the interests of the elite as opposed to the broader society. The challenge to state legitimacy in Cameroon requires a response which moves away from the dominant perception of statebuilding as a post conflict endeavour. It also requires the re-orientation of the approach to leadership within the society towards greater involvement of society in decision making processes.

There exists a need for genuine dialogue with the Anglophone population and other communities that feel excluded in order to rebuild civic trust and set them back on the path of statebuilding. Such a process cannot take place in a context where there is repression and intolerance to dissent. As such, it is essential that the context be transformed and processes aimed at statebuilding be anchored on the needs of society. Process based leadership gives room for a situational analysis that enables the leaders and society to develop a shared vision for a state that is desirable to both state and society. 
*Awah Leonide is a Program manager in the department of Training Grants and fellowships, specifically in charge of Higher education programs at the Council for the Development of Social Science Research in Africa (CORDESRIA).

\section{BIBLIOGRAPHY}

Anyangwe, Carlson (2008), Imperialistic Politics in Cameroun: Resistance and the Inception of the Restoration of the Statehood of Southern Cameroons (Bamenda: Langaa Publishing CIG)

Anyangwe, Carlson (2012), The secrets of an aborted Decolonisation (Bamenda: Langaa Publishing CIG)

Arriola, Leonardo (2013), Multi-ethnic coalitions in Africa: business financing of opposition election campaigns (New York: Cambridge University Press)

Atangana, Martin (2010), The end of French rule in Cameroon (Lanham, MD: University Press of America)

Ashew, Andrew (2016), Political philosophies and Nation Building in Cameroon: Grounds for remaking the Post Colony (Bamenda: Unique Printers)

Bass, Bernard \& Riggio, R. (2014), Transformational Leadership (New York: Routledge)

Bayart, Jean Francoise (1973), One-Party Government and Political Development in Cameroun, Journal of African Affairs, Vol: 72, Issue: 287, pp. $125-144$

Bachmann, Olaf (2013), Quasi Armies: Obstacles to, or Vehicle for StateBuilding in Central Africa (PHD Thesis: Kings College London) Retrieved at https://kclpure.kcl.ac.uk/portal/files/12625097/StudentthesisOlaf Bach mann 2013.pdf

Bogdandy, Armin \& Rüdiger. Wolfrum (2005) eds State-Building, NationBuilding, and Constitutional Politics in Post-Conflict Situations: Conceptual Clarifications and an appraisal of different approaches (Koninklijke Brill NV: Leiden)

Burns, James (2010), Leadership (New York: Harper Collins publishers) 
Clapman, Christopher (2007), Africa and the International system: The politics of State survival (Cambridge: Cambridge University press)

Chandler, David, \& Sisk, Timothy (2013), Routledge handbook of international Statebuilding (Milton Park, Abingdon, Oxon: Routledge)

Deltombe,Thomas, Domergue, Manuel and Tatsitsa, Joseph (2011) Kamerun!: une guerre cachée aux origines de la Françafrique 1948-1971, (Paris: La Découverte)

Durkheim, Emile (1957) Professional Ethics and Civic Morals. Translated by Cornelia Brookfield. (London: Routledge \& Kegan Paul)

Enonchong, Henry (1967), Cameroon constitutional law: federalism in a mixed common-law and civil-law system (Yaoundé: Centre d'edition et de production de manuels et d'auxiliaires de l'enseignement)

Erikesn, Stein (2015), The Liberal Peace Is Neither: Peacebuilding, State Building, and the Reproduction of Conflict in the Democratic Republic of Congo in Young, Tom ed. Readings in the International Relations of Africa (Indiana: Indiana University Press

Etonga, Mbu (1980), An Imperial Presidency: A Study of Presidential Power in Cameroon, in Kofele-Kale, Ndiva, An African Experiment in Nation Building: The Bilingual Cameroon Republic Since Reunification (Boulder: Westview Press)

Fenkam, Federick (2003), Les révélations de Jean Fochivé, Chef de la police politique des présidents Ahidjo et Biya (Paris: Tameris)

Galtung, Johan, 1976. Three Approaches to Peace: Peacekeeping, Peacemaking and Peace-building, in Johan Galtung\& Christian Ejlers, eds In Peace, War and Defence: Essays in Peace Research. Vol. 2, Copenhagen, 282-304

Grint, Keith (2010), Leadership: A Very Short Introduction (Oxford: University Press)

International Crises Group (2014), "Cameroon: Prevention Is Better than Cure”, Africa Briefing N¹01,Available at https://www.crisisgroup.org/africa/central-africa/cameroon/cameroonprevention-better-cure (Accessed 18 August 2019) 
ICG interview with Anglophone academics in Cameroon cited in International Crises Group Report (2017), Cameroon's Anglophone Crisis at the Crossroads, Africa Report No:250, Available online at (Nairobi and Brussels) https://www.crisisgroup.org/africa/centralafrica/cameroon/250-cameroons-anglophone-crisis-crossroads (Accessed 18 August 2019)

Joseph, Richard (1977), Radical Nationalism in Cameroun: Social Origins of the UPC Rebellion (Oxford: University Press)

Kofele, Kale (1980), An African experiment in Nation Building: the bilingual Cameroon Republic since reunification (Boulder: Westview press)

Konings, Piet and Nyamnjoh, Francis (1997), The Anglophone problem in Cameroon, Journal of modern African Studies, Vol: 35, No: 2, pp.207-229

Lemay-Hébert, Nicholas, Onuf, Nicholas Vojin, Rakić \& Bojanić, Petar eds (2014), Semantics of Statebuilding: Language, meanings and sovereignty (London: Routledge)

Mbembe, Achille (2001), On the post colony (Berkeley, CA: University of California press)

Mbembe, Achille (1986), Pouvoir des morts et languages des vivants: Les erraces de La memoire nationaliste au cameroun, Journal Politique Africaine, Vol: 2, No: 72, pp. 1-36

Ngoh, Julius (1996), History of Cameroon since 1800 (Limbe: Pressbook)

Northhouse, Peter (2016), Leadership: theory and practice (Los Angeles: SAGE Publications)

Olonisakin, Funmi, (2015), Re-conceptualising Leadership for effective peacemaking and human security in Africa, Strategic Review for Southern Africa, Vol. 37, Issue: 1

Olonisakin, Funmi \& Muteru, Alfred (2014), 'Reframing Narratives of Peacebuilding and State building in Africa', ALC Working Paper, No 16. Available at https://idl-bncidrc.dspacedirect.org/bitstream/handle/10625/56335/IDL56335.pdf?seq uence $=2$ \&isAllowed $=y$ 
Richard, Jospeh (1977), Radical nationalism in Cameroun: social origins of the U.P.C. rebellion (Oxford: Clarendon Press)

Richard Joseph (2002), Gaullist Africa: Cameroon under Ahmadu Ahidjo (Enugu: Forth Dimension Publishing Co)

Takougang, Joseph and Milton Krieger (1998), African State and Society in the 1990's, Cameroon's Political Crossroads, (Boulder: Westview Press)

Terretta, Meredith (2014), Nation of outlaws, State of Violence:

Nationalism, Grassfields tradition, and State Building in Cameroon (Athens, OH: Ohio University Press)

UNHCR 2018 Report 'Fleeing violence, Cameroonian refugee arrivals in Nigeria pass 30,000 ', available at https://www.unhcr.org/news/briefing/2018/11/5be551224/fleeingviolence-cameroonian-refugee-arrivals-nigeria-pass-30000.html (Accessed 17 May 2019)

Van de Wall Nicholas (1993), The politics of No reform in Cameroon in Callaghy, Thomas and Hemmed, John (eds.) Hemmed In responses to Africa's economic decline (New York: Columbia University press)

Victor T. Le Vine (1964), The Cameroons, from Mandate to Independence (Berkeley, CA: University of California press)

Weigert, Stephen (1996), Traditional religion and guerrilla warfare in modern Africa. (Basingstoke: Macmillan)

White House (2002), The National Security Strategy of the United States of America available online at https://www.state.gov/documents/organization/63562.pdf 